\title{
Lise Öğrencilerinde Sedanter Yaşam, Beslenme Davranışları ve Fazla Kiloluluk- Obezite Arasındaki İlişskinin Değerlendirilmesi: Bir Vaka Kontrol Çalışması
}

\author{
Eda KILINÇ ${ }^{1}$ (D) Asiye KARTAL ${ }^{2}$
}

Araștırma Görevlisi, Pamukkale Üniversitesi/Sağlık Bilimleri Fakültesi/Hemșirelik Bölümü/Halk Sağlığı Hemșireliği Anabilim Dalı/Denizli, Türkiye Doç. Dr. Pamukkale Üniversitesi/Sağlık Bilimleri Fakültesi/Hemşirelik Bölümü/Halk Sağlığı Hemşireliği Anabilim Dalı/Denizli, Türkiye

\section{Öz}

Giriş: Çocukluk çağı obezitesi, 21. yüzyılın en ciddi halk sağlığı sorunlarından biridir. Obezitenin en yaygın sebepleri arasında sedanter yaşam tarzı ve sağlıksız beslenme alışkanlıkları yer almaktadır. Amaç: Bu çalışmanın amacı bir grup adölesanda fazla kilolu ve obezite sıklığını belirlemek ve obezite oluşumunda sedanter yaşam tarzı ve beslenme davranışları ilişkisini incelemektir. Yöntem: Bu çalışma, kesitsel-vaka kontrol araştırmasıdır. Çalışmada, fazla kilolu ve obez olduğu tespit edilen 44 öğrenci ile kontrol grubu olarak alınan 53 öğrenci fazla kiloluluk ve obeziteye neden olabilecek çeşitli risk faktörleri bakımından incelenmiştir. Veri toplama aracı olarak sedanter yaşam tarzı ve beslenme davranışlarına ilişkin soru formu kullanılmıştır. Verilerin analizinde Mann-Whitney U testi, ki-kare ve lojistik regresyon analizi kullanılmışır. Bulgular: Öğrencilerde fazla kilolu ve obezite prevalansı \%10.9 bulunmuştur. Ailede kilolu birey varlı̆̆ı, günlük fiziksel aktivite süre ve sıklığı, günlük televizyon/bilgisayarda vakit geçirme ve ders çalışma süresi, okul içinde spor aktivitelerine katılmama ve ekran karşısında yiyecek yeme durumu vaka grubunda istatistiksel olarak anlamlı şekilde daha yüksektir. Ailede kilolu birey varlığ $(\mathrm{OO}=14.56, \% 95 \mathrm{GA}=$ 4.09-51.82), erkek cinsiyet $(\mathrm{OO}=2.95$, \%95 GA $=6.82-53.61)$, dershaneye/kursa gitme $(\mathrm{OO}=1.12$, \%95 GA $=.03-.45)$ ve bilgisayar/TV izlerken yiyecek yeme $(\mathrm{OO}=1.22, \% 95 \mathrm{GA}=.06-.72)$ fazla kiloluluk ve obezite riskini artırmaktadır. Sonuç: Bu çalışmada, öğrencilerde fazla kiloluluk ve obezite için en önemli risk faktörleri ailede kilolu birey varlığı, dershaneye/kursa gitme ve bilgisayar/televizyon izlerken yiyecek yemedir.

Anahtar Sözcükler: Adölesan, Fazla Kilo ve Obezite, Sedanter Yaşam, Beslenme Davranışı, Hemşirelik.

\section{Abstract}

\section{Assessment of The Relationship Between Sedentary Lifestyle, Nutritional Behaviors and Overweight-Obesity among High School Students: A Case Control Study}

Background: Childhood obesity is one of the most serious public health problems of the 21st century. Sedentary lifestyle and unhealthy eating habits are among the most common causes of obesity. Objectives: The aim of this study is to determine the prevalence of overweight and obesity in a group of adolescents and to examine the relationship between sedentary lifestyle and nutritional behaviors in obesity formation. Methods: This study is a cross-sectional nested case-control study. In the study, 44 students who were found to be overweight and obese and 53 students who were taken as a control group were examined in terms of various risk factors that may cause overweight and obesity. A questionnaire regarding sedentary lifestyle and nutritional behaviors was used as a data collection tool. In the analysis of the data, MannWhitney U, chi-square and logistic regression analyzes were used. Results: The prevalence of overweight and obesity among students was found to be $10.9 \%$. The presence of overweight individual in the family, the duration and frequency of daily physical activity, daily television/computer time and study time, not participating in sports activities at school, and eating food in front of the screen were statistically significantly higher in the case group. The presence of an overweight family member $(\mathrm{OR}=14.56$, \%95 GA = 4.09-51.82), male gender $(\mathrm{OR}$ $=2.95,95 \% \mathrm{CI}=6.82-53.61)$, going to the course $(\mathrm{OR}=1.12, \% 95 \mathrm{GA}=.03-.45)$ and eating food while watching a computer/television $(\mathrm{OR}$ $=1,22$, \%95 GA = .06-.72) increase the risk of overweight and obesity. Conclusion: In this study, the most important risk factors for overweight and obesity among students are presence of overweight individuals in the family, going to classrooms/courses and eating food while watching computers/television.

Key Words: Adolescent, Overweight and Obesity, Sedentary Life, Nutritional Behavior, Nursing.

Geliş Tarihi / Received: 17.03.2021 Kabul Tarihi / Accepted: 27.12. 2021

Correspondence Author: Araştırma Görevlisi, Pamukkale Üniversitesi/Sağlık Bilimleri Fakültesi/Hemşirelik Bölümü/Halk Sağlı̆ı Hemşireliği Anabilim

Dal1/Denizli, Türkiye Telefon: +90 5455619683 E-posta: ekilinc@pau.edu.tr

Cite This Article: Kılıņ E, Kartal A. Lise Öğrencilerinde Sedanter Yaşam, Beslenme Davranışları ve Fazla Kiloluluk-Obezite arasındaki İlişkinin Değerlendirilmesi: Bir Vaka Kontrol Çalışması Dokuz Eylül Üniversitesi Hemşirelik Fakültesi Elektronik Dergisi. 2022; 15(1): 30-39. 
C

ocukluk çağı obezitesi, 21. yüzyılın en ciddi halk sağlığı sorunlarından biridir. Küresel boyutta sağlık için bir risk oluşturan obezite ve şişmanlık, vücuda alınan enerji ile harcanan enerji arasındaki dengesizlik sonucu ortaya çıkmakta ve ekonomik, genetik, çevresel, psikolojik, kültürel olarak çok faktörlü bileșenleri bulunmaktadır (1-3).

Dünya Sağlık Örgütü (DSÖ) verilerine göre çocuk ve ergenler arasında (5-19 yaş arası) aşırı kilo ve obezite prevalansı, 1975 'te \%4 iken 2016'da \%18'e çıkarak çarpıcı bir şekilde yükselmiş olup artış hem erkek hem de kadınlar arasında eşit oranda tespit edilmiştir (4). Türkiye'de ise adölesanlarda yapılan araştırmalarda fazla kiloluluk prevalansı $\% 12,4-\% 23,0$ arasında iken obezite prevalansı \%6,5-\%10,1 arasında bulunmuştur (5-7). Dünyada giderek artan obezite prevelansını COVID-19'a bağlı alınan önlemlerde tetiklemiş̧ir. Çin'de yapılan bir çalışmada öğrencilerin okullar kapanmadan önce fazla kiloluluk prevelansı \%17.07 iken okullar kapandıktan sonra \%17.43' e yükselmiştir (8). Kore'de yapılan bir çalışmada ise COVID-19 tedbirlerine bağlı öğrencilerin Beden Kitle İndeksi (BKİ) okullar kapanmadan önce $26.7 \pm 4.6$ iken okullar kapandıktan sonra 27.7 \pm 4.6 'a yükselmiştir (9). Bu sonuçlardan da görüldüğ̈̈ gibi dünyada ve ülkemizde yaygın olarak görülen fazla kiloluluk ve obezite sorunu giderek artmaktadır.

Sedanter yaşam ve sağlıksız beslenme davranışları fazla kiloluluk ve obezite nedenlerinin başında gelmektedir (4). Adölesanların televizyon izleme/bilgisayarda oyun oynama/video izleme ve diğer sedanter yaşam davranışlar ile birlikte daha fazla yağ alımı, tatlı ve tuzlu atıştırmalıklar, gazlı içecekler, az miktarda meyve ve sebze alımı gibi sağlıksız beslenme davranışları obezite ile doğrudan ilişkilidir $(10,11)$. Ayrıca, yiyeceklerin televizyonda en çok reklamı yapılan ürün olduğu ortaya çıktığı için televizyon izlerken yemek yeme kötü yemek seçim sıklığının artmasına yol açmaktadır. Yüksek oranda tatlandırılmış ürünler (örneğin, şekerli içecekler ve şeker bakımından zengin tahıllar) ve fast-foodlar ise en çok reklamı yapılan yiyeceklerdendir. Dolayısıyla hareketsizliğe iten bu davranışlar aynı zamanda yanlış beslenme tercihlerine de itmekte böylelikle obezite riskini artırmaktadır $(6,10,12,13)$.

Adölesanlarda fazla kiloluluk ve obeziteye neden olan bu faktörler birçok çalışma ile incelenmiştir. Sri Lanka'da yapılan bir vaka-kontrol çalışmasında obez adölesanların kahvaltıyı atlaması, meyve tüketiminin haftada 4 günün altında olması ve günde 2 saatten fazla ekran başında oturmanın obezite riskini artırdı ğı belirlenmiştir (14). Korede yapılan bir çalışmada cep telefonu bağımlılığının obeziteye sebep olduğu belirlenmiştir (15). Türkiye'de yapılan çalışmalarda ise ailede obez birey varlığı $(5,7)$, fiziksel aktivite sıklığının az olması, televizyon ve bilgisayar karşısında oturarak atıştırma şeklindeki beslenme düzeninin obezite için bir risk olduğu yapılan araştırmalar ile de desteklenmektedir (7). Ayrıca, fazla kiloluluk ve obeziteye neden olan faktörlerden biri de öğrencilerin hayatında fazla zaman geçirdikleri alan olan okullardır. Literatür incelendiğinde, lise öğrencilerinin okulda yaptıkları çeşitli davranışların fazla kiloluluk ve obezite ile ilişkisinin incelendiği çalışmalar görülmüştür $(5-7,16)$. Adölesan dönemde okulla ilişkili olduğu düşünülen ve sedanter yaşama iten risk faktörleri; ev ödevi sayısının fazla olması, okul saatleri dışında ders amaçlı kurslara katılma, okulda fiziksel aktiviteye katılmama, bir spor takımına üye olmama veya okula motorlu araçla gidip-gelmedir $(12,16,17)$. Fazla kiloluluk ve obeziteye neden olan bu faktörler çocukların ileri yaşta daha büyük sağlık sorunları yaşamasına neden olabilir.

Aşırı kilolu ve obez çocuk/ergenlerin erişkinlikte de obez olması, genç yaşta diyabet, kardiyovasküler hastalıklar gibi bulaşıcı olmayan hastalıklara maruz kalma olasılığıı artırmakta ve olumsuz psikolojik etkiler yaratmaktadır (2). Bu sebeple, obeziteyi önleme ve kardiyovasküler risk faktörlerinin erken yönetimi klinik tedaviden daha etkili ve daha ekonomik bir yöntem olarak kabul görmektedir. Obezitenin önlenebilmesi için sağlık profesyonelleri, toplumun önemli bir grubu olan lise öğrencilerinde obezite prevalansını ve obeziteye neden olan sağlıksız davranışları belirlemelidir. Yaptığımız incelemeler sonucunda ülkemizde adölesanlarda fazla kiloluluk ve obeziteye neden olan beslenme ve fiziksel aktiviteye ilişkin faktörler incelenmesine rağmen okula ilişkin faktörlerin incelenmemesi literatürde bu konuda boşluğun olduğunu göstermektedir. Öğrencilerin ev dışında en fazla zamanı okulda geçirmeleri fazla kilolu ve obeziteye sebep olan durumların okulla ilişkili olup olmadığını incelemeyi gerektirmektedir. Bu sebepten dolayı çalışmamızda hem bilinen risk faktörleri hem de çok az kanıt bulunan (17) okulla ilişkili sedanter yaşam ile fazla kiloluluk ve obezite arasındaki ilişki incelenmiştir. Bu çalışmanın amacı bir grup adölesanda fazla kiloluluk ve obezite sıklı̆ı̆ı ı belirlemek ve fazla kiloluluk ve obezite oluşumunda sedanter yaşam ve beslenme davranışları ilişkisini incelemektir.

Araştırmanın amacı: Bu çalışmanın amacı bir grup adölesanda fazla kilolu ve obezite sıklığını belirlemek ve obezite oluşumunda sedanter yaşam tarzı ve beslenme davranışları ilişkisini incelemektir.

\section{Araştırma Sorulart:}

Adölesanlarda fazla kiloluluk ve obezite prevalansı nedir?

Vaka ve kontrol grubunun sedanter ve beslenme davranışları arasında fark var mıdır?

Vaka ve kontrol grubu ile ebeveyn BKİ değerleri arasındaki ilişki nedir?

Adölesanlarda fazla kiloluluk ve obeziteye sebep olan risk faktörleri nelerdir?

\section{Yöntem}

\section{Araştırmanın Tipi}

$\mathrm{Bu}$ çalışma, kesitsel-vaka kontrol araştırmasıdır.

\section{Araştırmanın Yapıldı̆̆ Yer}

Araştırma Türkiye'nin batısında bulunan Millî Eğitim Bakanlığı'na bağlı bir fen lisesinde yapılmıştır. Araştırmanın yürütüldüğü okul, bulunduğu ilde akademik olarak en başarılı öğrencilerin olduğu okul olması sebebiyle öğrencilerin çok ders çalıştı̆̆ düşünülerek seçilmiştir. Araştırmamızın sorularından biri de okula ilişkin (ders çalışma süresi, ödevler, kurslar vs.) özelliklerin fazla kiloluluk ve obeziteye etkisini belirlemek olduğu için bu özellikteki bir okulun araştırmaya dahil edilmesi uygun görülmüştür. 


\section{Araştırmanın Evreni/Örneklemi}

Araştırmanın evrenini fen lisesinin öğrencileri $(\mathrm{N}=549)$ oluşturmuştur. Türk çocuk ve adölesanlarda (2-20 yaş arası) yaşa göre vücut ağırlığı ölçülerinin değerlendirilmesinde BKİ değeri 5. persentilin altında ise düşük kilolu, 5. persentil ve üzeri ile 85. persentil arasında ise normal kilolu, 85. persentil ve üzeri ile 95. persentil arasında ise fazla kilolu, 95 . persentil ve üzeri ise obez olarak tanımlanmaktadır (18). BKİ değeri 25 ve üzerinde (85. persentil ve üzeri) olan fazla kilolu ve obez öğrenciler vaka grubunu oluşturmuştur. Kontrol grubu ise vaka grubunun yaş değişkenine göre eşleştirme yapılarak seçilmiştir. Cinsiyet oranının kadın öğrencilerde ağırlıklı olması sebebiyle cinsiyet değişkeni üzerinde eşleştirme yapılamamış bu durum araştırmanın sınırlılı̆̆ı olarak belirlenmiștir. Kontrol grubunu, vaka grubundaki öğrenci sayısına yakın ve persentil değeri 85 'in altında olan öğrenciler oluşturmuştur. Araştırmaya dahil edilme kriterleri, vaka grubu için BKI'si 85. persentil ve üzerinde olma, araştırmaya katılmayı kabul etme ve veli onamı olmadır. Araştırmanın örneklem sayısı Yılmaz ve Mayda (2017)'nın vaka kontrol çalışmasındaki baba BKİ değeri referans alınarak hesaplanmıştır. Buna göre etki büyüklüğü .57 , gücü $.80, \alpha=.05$ olarak belirlenmiş, böylelikle vaka grubu 39 kontrol grubu 39 olacak şekilde en az 78 katılımcının çalışmaya dahil edilmesi gerekmektedir (6). Okulda persentil değeri 85 ve üzerinde olan toplam öğrenci sayısı 60'dır. Çalışmaya katılmayı kabul eden 44 öğrenci araştırmanın vaka grubunu oluşturmuştur. Vaka grubundaki öğrencilerin çalışmaya katılmama sebepleri bazı öğrencilerin aile onamının olmaması ve bazı öğrencilerin vaktinin olmadığını bildirmesidir. BKİ değeri 85. persentilin altında olan 53 öğrenci ise kontrol grubunu oluşturmuştur.

\section{Veri Toplama Araçları}

Veri toplama araçları olarak; öğrencilerin sosyo-demografik özellikleri ile literatür araştırması doğrultusunda risk oluşturabileceği düşünülen sedanter yaşam ve beslenme davranışları ile ilgili soru formu kullanılmıştır $(6,12,15,16,17,19,20,21,22)$. Bu formlarda toplamda 19 kapalı uçlu soru bulunmakta olup araştırmacılar tarafından oluşturulmuş, geçerliliği ve güvenilirliği yapılmamıştır. Literatür doğrultusunda oluşturulan bu soru formunun kullanılmasının sebebi fazla kiloluluk ve obeziteye neden olan faktörlerin ölçme aracıyla ölçülemiyor olmasıdır. Yaptığımız incelemeye göre araştırma konumuz ile ilgili vaka kontrol tipi araştırmaların hepsinde bu şekilde soru formları kullanılmıştır $(6,12,19,21,15,22)$.

Sosyo-demografik soru formu

$\mathrm{Bu}$ form araştırmacılar tarafından literatür incelemesi yapıldıktan sonra oluşturulmuştur. Öğrencilerin yaşı, cinsiyeti, eğitim durumu, ailenin ekonomik düzeyi sorularının yanı sıra fazla kiloluluk ve obezite için risk oluşturan anne ve babanın boylarıkiloları ve ailede kilolu birey varlığı sorularını da içermektedir. Ailede kilolu birey varlı̆̆ı "ailenizde (anne, baba, kardeş) kilolu birey var mı?" şeklinde sorulmuştur.

Sedanter yaşam ve beslenme davranışlarına ilişskin soru formu

$\mathrm{Bu}$ formda öğrencilerin son bir yıl içinde gerçekleştirdiğgi günlük fiziksel aktivite süresi, haftalık fiziksel aktivite sıklığı, okulda katıldığı spor takımı, günlük ders çalışma süresi, günlük televizyon/bilgisayar izleme süresine ilişkin sorular bulunmaktadır. Bu sorular üç veya dört seçenekten oluşacak şekilde kategorize edilmiştir. Örneğin "Günlük bilgisayarda vakit geçirme süren kaç

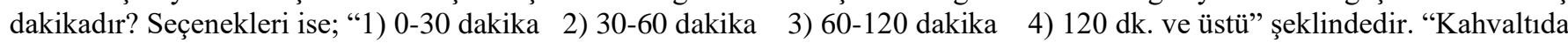
yenilen besinlerin içeriği nelerdir?" sorusu için seçenekler "1) Protein ağırlıklı (Peynir, yumurta, süt vs.) 2) Karbonhidrat ağırlıklı (Börek, poğaça, simit vs.)" şeklinde sunulmuştur. Tablo 1'de soru ve cevaplar gösterilmiştir. Spor aktivitelerine katılım “okul içinde herhangi bir spor aktivitelerine (voleybol, futbol, hentbol vs.) katılır mısın?” şeklinde sorulmuştur.

Öğrencilerin beslenme alışkanlıklarına ilişkin kahvaltı ve kantinle ilgili sorular mevcuttur. Kantinler öğrencilerin kalorili besin (simit, çikolata, bisküvi, poğaça, tost vs.) tükettikleri yerler olarak belirlenmiştir (24). Bir araştırmaya göre ise öğrencilerin \%66,6'sı sabah kahvaltısını okulda yapmaktadır (25). Bu sebeple araştırmada okul içerisinde tüketilen beslenme davranışlarına ağırlık verilmiştir.

\section{Verilerin Toplanmast}

Araştırma, Ekim 2019-Aralık 2019 tarihleri arasında gerçekleştirilmiştir. İlk aşamada, okuldaki tüm öğrencilerin boy-kilo ölçümleri araştırmacılar ve okulun iki beden eğitimi öğretmeni desteği ile gerçekleştirilmiştir. Bu destekte beden eğitimi öğretmenleri öğrenciler ile araştırmacılar arasındaki iletişimi sağlamışlardır. Ölçümler, araştırmacılar tarafından yapılmıştır. Bir araştırmacı boy ve kilo ölçümünü yaparken diğer araştırmacı elektronik olarak bilgisayara kayıt etmiştir. Ölçümler beden eğitimi ders saatlerinde yapılmıştır. Ölçümlerde boy ölçümü için portatif metal boy ölçer kullanılmış olup öğrencilerin ayakkabıları çıkarılarak uygun pozisyonda ölçülmüştür. Kilogram ölçümü için ise EKS dijital baskül 8873 (100 gram hassasiyette) kullanılmıştır. Kilo ölçümünde öğrencilerin üzerindeki kalın kıyafetler (ceket, hırka vs.) ve ayakkabılar çıkarılmıştır. Yapılan ölçümlere göre, öğrencilerin BKİ ölçümleri DSÖ ve Türk çocuk ve adölesanlarda (2-20 yaş arası) yaşa göre vücut ağırllğı ölçüleri referans alınarak 85. persentil ve üzeri fazla kilolu, 95 . persentil ve üzeri obez olarak kabul edilmiştir $(3,25)$.

Veri toplama sürecinin ikinci aşamasında, vaka ve kontrol grubu sosyo-demografik, sedanter yaşam ve beslenme davranışlarına ilişkin soru formlarını cevaplamışlardır. Formlar öğrenciler tarafından öz-bildirime dayalı olarak doldurulmuştur. Veri toplama süreci araştırmacıların gözlemi altında ve yaklaşık 30 dakika sürmüştür.

\section{Araştırmanın Değişskenleri}

Araştırmanın bağımlı değişkenleri; fazla kiloluluk ve obezitedir. Bağımsız değişkenleri; yaş, cinsiyet, ailenin ekonomik düzeyi, ailede kilolu birey varlığı, ebeveynlerin BKİ değeri, fiziksel aktivite sıklığı, fiziksel aktivite süresi, günlük televizyon/bilgisayar izleme süresi, günlük akıllı telefonda vakit geçirme süresi, günlük okul harici ders çalışma/ödev yapma süresi, dersaneye/kursa gitme, okula ulaşım, okul içinde spor aktivitelerine katılma, kahvaltıda yenilen besinlerin içeriği, öğle yemeğini yeme alanı, öğle yemeğinde yenilen besinlerin çeşidi ve bilgisayar/TV izlerken yiyecek yeme durumudur.

\section{Verilerin Değerlendirilmesi}

Verilerin değerlendirilmesinde IBM Predictive Analytics Software (PASW) Statistical Product and Service Solutions (SPSS, Chicago, IL, USA) 22 programı kullanılmıştır. Verilerin normal dağılıma uygunluğu Shapiro-Wilk testi ile incelenmiştir. Dağılımları normal olan değişkenlere parametrik testler, dağılımları normal olmayan değişkenlere ise non-parametrik testler uygulanmıştır. Öğrencilerin bireysel özellikleri, sedanter yaşam ve beslenme davranışlarına ilişkin sayı ve yüzde dağılımları, 
vaka ve kontrol grupları arasında sedanter yaşam ve beslenme davranışları ile ilgili özelliklerin incelenmesinde ki-kare analizi kullanılmıştır.

Öğrencilerin ebeveynlerinin BKİi ankette boy kilo ölçüm değerlerinin sorulması ile öğrenilmiştir. BKİ'si 85. persentil ve üzerinde olan ve olmayan öğrencilerin ebeveynlerin BKİ ortalamaları arasında fark olup olmadığını belirlemek için MannWhitney U testi kullanılmıştır. Ayrıca araştırmada fazla kiloluluk ve obezite için risk faktörlerini belirlemek amacıyla tek değişkenli ve çoklu lojistik regresyon analizi yapılmıştır. Kurulan modelin uyum iyiliği Hosmer-Lemeshow test istatistiği ile hesaplanmıştır. Regresyon modeline ki-kare testi sonucunda vaka ve kontrol grubu arasında anlamlı ilişki bulunan değişkenler (cinsiyet, ailede kilolu birey varlığı, günlük fiziksel aktivite sıklığı ve süresi, günlük TV izleme süresi, günlük bilgisayarda vakit geçirme süresi, günlük okul harici ders çalışma/ödev yapma süresi, dershaneye/kursa gitme, okul içinde spor aktivitelerine katılma, TV karşısında yiyecek yeme) alınmıştır. Tek değişkenli lojistik regresyonda anlamlı bulunan değişkenler çoklu lojistik regresyona dahil edilerek fazla kiloluluk ve obeziteye neden olan en önemli risk faktörleri belirlenmiştir. İstatistiksel anlamlılık düzeyi olarak $p<.05$ kabul edilmiştir.

\section{Araştırmanın Etik Yönü}

Çalışmanın etik kurul onayı Girişimsel Olmayan Klinik Araştırmalar Etik Kurulu (Tarih: 22/01/2019 Sayı: 60116787020/16167) tarafından onaylanmıştır. Çalışmanın yürütüleceğgi okul için T.C. Millî Eğitim Bakanlığı İl Milli Eğitim Müdürlüğü'nden resmi izin alınmıştır. Ayrıca araştırmaya dahil olan tüm öğrenciler ve velilerinden sözlü ve yazılı onam alınmıştır.

\section{Bulgular}

Araştırmadaki öğrencilerin 324'ü kadın (\%59.1) 225'i erkek (\%40.9) cinsiyettedir. Araştırmanın birinci kısmını oluşturan öğrencilerin \%10.9'unun (60 öğrenci) BKİ değeri 85. persentil ve üzerinde bulunmuştur. Vaka grubundaki öğrencilerin ise \%16.6's1 (10 öğrenci) obez iken \%83.4'ü (50 öğrenci) fazla kiloludur. Vaka grubundaki öğrencilerin 77.3'ünü erkek öğrenciler \%22.7'sini ise kadın öğrenciler oluşturmaktadır. Vaka grubunun içerisinde en fazla 9. sınıf (\%68.2) öğrencileri bulunmaktadır. 
Tablo 1. Vaka ve Kontrol Grubunun Demografik Verileri. Sedanter ve Beslenme Davranışları Arasındaki Farklar

\begin{tabular}{|c|c|c|c|c|c|c|c|c|}
\hline \multirow[b]{2}{*}{ Özellik } & \multicolumn{2}{|c|}{ Vaka $(n=44)$} & \multicolumn{2}{|c|}{ Kontrol (n = 53) } & \multicolumn{2}{|c|}{ Toplam } & \multirow[b]{2}{*}{$\mathbf{X}^{2}$} & \multirow[b]{2}{*}{$\mathbf{p}$} \\
\hline & Sayı & Yüzde & Sayı & Yüzde & Sayı & Yüzde & & \\
\hline \multicolumn{9}{|l|}{ Cinsiyet } \\
\hline $\mathrm{K}_{12}$ & 10 & 22.70 & 45 & 84.90 & 55 & 56.70 & \multirow{2}{*}{37.85} & \multirow{2}{*}{$<.001$} \\
\hline Erkek & 34 & 77.30 & 8 & 15.10 & 42 & 43.30 & & \\
\hline \multicolumn{9}{|l|}{ Yaș } \\
\hline On dört & 30 & 46.20 & 35 & 53.80 & 65 & 67.00 & & \\
\hline On beș & 8 & 57.10 & 6 & 42.90 & 14 & 14.40 & 1.85 & .391 \\
\hline On alt1 & 6 & 33.30 & 12 & 66.70 & 18 & 18.60 & & \\
\hline Ailede Kilolu Birey Varlığı & & & & & & & & \\
\hline Evet & 34 & 77.30 & 15 & 28.30 & 49 & 48.00 & & \\
\hline Hayır & 10 & 22.70 & 38 & 71.70 & 50.5 & 49.50 & 23.06 & $<.001$ \\
\hline Ailenin Ekonomik Düzeyi & & & & & & & & \\
\hline İyi & 10 & 22.70 & 11 & 20.80 & 21 & 21.60 & & \\
\hline Orta & 25 & 56.80 & 30 & 56.60 & 55 & 56.70 & 0.09 & .954 \\
\hline Kötü & 9 & 20.50 & 12 & 22.60 & 21 & 21.60 & & \\
\hline & (n & & & & & & & \\
\hline Haftalık Fiziksel Aktivite Sıklığı & 35) & & $(\mathrm{n}=50)$ & & & & & \\
\hline Her gün & 10 & 28.60 & 18 & 36.00 & 28 & 32.90 & & \\
\hline İki günde bir & 6 & 17.10 & 20 & 40.00 & 26 & 30.60 & & \\
\hline Üç dört günde bir & 13 & 37.10 & 2 & 4.00 & 15 & 17.60 & 16.76 & $<.001$ \\
\hline Haftada bir & 6 & 17.10 & 10 & 20.00 & 16 & 18.80 & & \\
\hline & (n & & & & & & & \\
\hline Günlük Fiziksel Aktivite Süresi & 35) & & $(\mathrm{n}=50)$ & & & & & \\
\hline 30 dakika altı & 4 & 11.40 & 0 & 0.00 & 4 & 4.70 & & \\
\hline 30-59 dakika arası & 26 & 74.30 & 34 & 68.00 & 60 & 70.60 & 8.44 & $<.011$ \\
\hline 60 dakika ve üstü & 5 & 14.30 & 16 & 32.00 & 21 & 24.70 & & \\
\hline Günlük TV İzleme Süresi & & & & & & & & \\
\hline 30 dakika altı & 29 & 65.90 & 43 & 81.60 & 72 & 74.20 & & \\
\hline 30-59 dakika arası & 8 & 18.20 & 10 & 18.90 & 18 & 18.60 & & \\
\hline 60-119 dakika arası & 6 & 13.60 & 0 & 0.00 & 6 & 6.20 & 9.18 & $<.05$ \\
\hline 120 dakika ve üstü & 1 & 2.30 & 0 & 0.00 & 1 & 1.00 & & \\
\hline Günlük Bilgisayarda Vakit Geçir & & & & & & & & \\
\hline 30 dakika altı & 26 & 59.10 & 47 & 88.70 & 73 & 75.30 & & \\
\hline 30-59 dakika arası & 8 & 18.20 & 4 & 7.50 & 12 & 12.40 & & \\
\hline 60-119 dakika arası & 7 & 15.90 & 2 & 3.80 & 9 & 9.30 & 12.42 & $<.001$ \\
\hline 120 dakika ve üstü & 3 & 6.80 & 0 & 0.00 & 3 & 3.10 & & \\
\hline Günlük Akıllı Telefonda Vakit G & & & & & & & & \\
\hline 30 dakika altı & 3 & 6.80 & 2 & 3.80 & 5 & 5.20 & & \\
\hline 30-59 dakika arası & 16 & 36.40 & 15 & 28.30 & 31 & 32.00 & & \\
\hline 60-119 dakika arası & 15 & 34.10 & 25 & 47.20 & 40 & 41.20 & 1.96 & .585 \\
\hline 120 dakika ve üstü & 10 & 22.70 & 11 & 20.80 & 21 & 21.60 & & \\
\hline Günlük Okul Harici Ders Çalış & & & & & & & & \\
\hline Süresi & & & & & & & & \\
\hline 2 saat ve altı & 23 & 52.30 & 34 & 64.20 & 57 & 58.80 & & \\
\hline $2-4$ saat aras 1 & 17 & 38.60 & 13 & 24.50 & 30 & 30.90 & 8.07 & $<.011$ \\
\hline 4 saat ve üstü & 4 & 9.10 & 6 & 11.30 & 10 & 10.30 & & \\
\hline Dershaneye/Kursa Gitme & & & & & & & & \\
\hline Evet & 26 & 59.10 & 16 & 30.20 & 42 & 43.30 & & \\
\hline Hayır & 18 & 40.90 & 37 & 69.80 & 55 & 56.70 & 8.18 & $<.001$ \\
\hline Okula Ulașim & & & & & & & & \\
\hline Servis/Dolmuş vs. & 28 & 63.60 & 40 & 75.50 & 68 & 70.10 & 160 & 20工 \\
\hline Yürüyerek & 16 & 36.40 & 13 & 24.50 & 29 & 29.90 & 1.60 & . 205 \\
\hline Okul İçinde Spor Aktivitelerine I & & & & & & & & \\
\hline Evet & 5 & 11.40 & 16 & 30.20 & 21 & 21.60 & & \\
\hline Hayır & 39 & 88.60 & 37 & 69.80 & 76 & 78.40 & 5.03 & $<.05$ \\
\hline Kahvaltıda Yenilen Besinlerin İç & & & & & & & & \\
\hline Protein Ağırlıklı & 25 & 56.80 & 34 & 73.90 & 56 & 65.60 & 01 & $0 \% 4$ \\
\hline Karbonhidrat Ağırlıklı & 19 & 43.20 & 12 & 26.10 & 31 & 34.40 & 2.91 & .084 \\
\hline Öğle Yemeğini Yeme Alanı & & & & & & & & \\
\hline Kantin & 12 & 27.90 & 8 & 16.30 & 20 & 21.70 & & \\
\hline Yemekhane & 27 & 62.80 & 37 & 75.50 & 64 & 69.60 & 1.98 & .374 \\
\hline Diğer & 4 & 9.30 & 4 & 8.20 & 8 & 8.70 & & \\
\hline Öğle Yemeğinde Yenilen Besin Ç & & & & & & & & \\
\hline Ev Yemekleri & 28 & 65.10 & 39 & 79.60 & 67 & 72.80 & & \\
\hline Fast food & 13 & 30.20 & 8 & 16.30 & 21 & 22.80 & 2.61 & .275 \\
\hline Diğer & 2 & 4.70 & 2 & 4.10 & 4 & 4.30 & & \\
\hline Bilgisayar/TV İzlerken Yiyecek & & & & & & & & \\
\hline Evet & 27 & 61.40 & 16 & 30.20 & 43 & 44.30 & & \\
\hline Hayır & 17 & 38.60 & 37 & 69.80 & 54 & 55.70 & 9.46 & $<.001$ \\
\hline
\end{tabular}

$p<.05 p<.01 p<.001$

Araştırmanın ikinci kısmına ilişkin vaka grubundaki öğrencilerin yaş ortalaması $14.75 \pm .81$ kontrol grubundaki öğrencilerin ise $14.94 \pm .98$ 'dir. Vaka ve kontrol grubundaki öğrencilerin demografik verileri, sedanter yaşam ve beslenme davranışları arasındaki farklar Tablo 1'de belirtilmiştir (Tablo 1). Çalışmada vaka ve kontrol grupları arasında bazı değişkenler yönünden 
anlamlı farklılıklar bulunmuştur. Bu değişkenler; öğrencilerin ailelerinde kilolu birey varlığı $\left(x^{2}=23.06 p<.001\right)$, fiziksel aktivite sıklı̆ı $\left(x^{2}=16.76 p<.001\right)$ ve süresi $\left(x^{2}=8.44 p<.05\right)$, günlük televizyonda $\left(x^{2}=9.18 \mathrm{p}<.05\right)$ ve bilgisayarda vakit geçirme süresi $\left(x^{2}=12.42 p<.01\right)$, günlük ders/ödev yapma süresi $\left(x^{2}=8.07 p<.05\right)$, dershaneye/kursa gitme durumları $\left(x^{2}=\right.$ $8.18 p<.05)$, okul içinde spor aktivitelerine katılma durumları $\left(x^{2}=5.03 p<.05\right)$ ve bilgisayar/TV izlerken yiyecek yeme durumlarıdır.

Tablo 2. Vaka ve Kontrol Grubu ile Ebeveyn BKi Değerleri Arasındaki İlişki

\begin{tabular}{|c|c|c|c|c|c|c|}
\hline & Gr & & & & & \\
\hline & & (Medyan. & & Kontrol & (Medyan. & \\
\hline Özellikler & $\mathbf{n}$ & $\mathrm{X} \pm \mathrm{SS})$ & $\mathbf{n}$ & $\mathrm{X} \pm \mathrm{SS})$ & $Z^{*}$ & $P$ \\
\hline \multirow[t]{2}{*}{ Anne BKİ } & \multirow{2}{*}{21} & $27.10 \pm 6.00$ & \multirow{2}{*}{35} & $23.50 \pm 2.63$ & 20 & \multirow{2}{*}{$<.001$} \\
\hline & & $27.91 \pm 4.14$ & & $24.05 \pm 3.18$ & -3.64 & \\
\hline \multirow[t]{2}{*}{ Baba BK } & \multirow{2}{*}{27} & $26.30 \pm 5.65$ & \multirow{2}{*}{47} & $24.65 \pm 1.70$ & 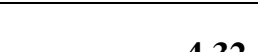 & \multirow{2}{*}{$<.001$} \\
\hline & & $28.08 \pm 4.79$ & & $24.67 \pm 3.57$ & & \\
\hline
\end{tabular}

*Mann-Whitney U testi $X=$ Ortalama $S S=$ Standart Sapma $p<.001$

Vaka ve kontrol grubundaki öğrencilerin ebeveynlerinin BKİ değerleri arasında anlamlı fark (anne BKİ $Z=-3.64 p<.001$; baba BKİ $Z=-4.32 p<.001$ ) vardır. Şişman ve obez öğrencilerin ebeveynlerinin BKİ değerleri kontrol grubuna göre yüksek bulunmuştur. Vaka ve kontrol grubundaki öğrencilerin ve ebeveynlerinin BKİ değerleri Tablo 2'de verilmiştir (Tablo 2).

Tablo 3. Tek Değişkenli Lojistik Regresyon Analizine Göre Fazla Kiloluluk ve Obeziteye Sebep Olan Risk Faktörleri

\begin{tabular}{|c|c|c|c|c|}
\hline & & & $\% 95$ & GA \\
\hline Değişkenler & $p$ & O.O. & Minimum & Maksimum \\
\hline Cinsiyet (erkek) & $<.001$ & 2.951 & 6.822 & 53.617 \\
\hline Ailede kilolu birey varlığı (Evet) & $<.001$ & 8.613 & 0.046 & 0.293 \\
\hline Fiziksel aktivite sıklığı (iki gün ve daha az) & .381 & 1.555 & 0.579 & 4.172 \\
\hline Fiziksel aktivite sıklığı (üç gün ve daha fazla) & .906 & 1.080 & 0.302 & 3.859 \\
\hline Fiziksel aktivite süresi (60 dk. ve üstü) & .069 & 0.354 & 0.116 & 1.083 \\
\hline TV izleme süresi (30 dk. ve üstü) & .092 & 2.224 & 0.879 & 5.628 \\
\hline Bilgisayarda vakit geçirme süresi (60 dk. ve üstü) & $<.001$ & 5.423 & 1.915 & 15.354 \\
\hline Okul harici ders çalışma/ödev yapma süresi (2-4 saat) & $<.011$ & 0.283 & 0.115 & 0.692 \\
\hline $\begin{array}{l}\text { Okul harici ders çalışma/ödev yapma süresi (4 saat ve } \\
\text { üstü) }\end{array}$ & .183 & 0.377 & 0.090 & 1.585 \\
\hline Dershaneye/kursa gitme (Evet) & $<.012$ & 3.340 & 1.442 & 7.735 \\
\hline Okul içinde spor aktivitelerine katılma (Hayır) & .092 & 0.450 & 0.178 & 1.138 \\
\hline Bilgisayar/TV izlerken yiyecek yeme (Evet) & $<.011$ & 3.673 & 1.579 & 8.541 \\
\hline
\end{tabular}

$O O=$ Odds Oran1. GA = Güven Aralığ $p<.01 \quad p<.001$

Lojistik regresyon modeli istatistiksel olarak anlamlı ve iyi uyum göstermiştir (Hosmer-Lemeshow uyum iyiliği $/{ }^{2}=14.515 ; p$ $=.430>.05$ ). Bağımsız değişkenler bağımlı değişkeninin \%57'sini açıklamaktadır (Nagelkerke $R^{2}$ ). Tek değişkenli lojistik regresyon analizi sonucuna göre ailede kilolu birey varlığ $(\mathrm{OO}=8.61, \% 95 \mathrm{GA}=6.82-53.61)$, erkek cinsiyet $(\mathrm{OO}=2.95$, \%95 $\mathrm{GA}=6.82-53.61)$, bilgisayarda günlük $60 \mathrm{dk}$. dan fazla vakit geçirme $(\mathrm{OO}=5.43, \% 95 \mathrm{GA}=1.91-15.35)$, dershaneye/kursa gitme $(\mathrm{OO}=3.34, \% 95 \mathrm{GA}=1.44-7.73)$ ve bilgisayar/TV izlerken yiyecek yeme $(\mathrm{OO}=3.67, \% 95 \mathrm{GA}=1.57-8.54)$ fazla kiloluluk ve obezite riskini artırmaktadır (Tablo 3). 
Tablo 4. Çoklu Lojistik Regresyon Analizine Göre Fazla Kiloluluk ve Obeziteye Sebep Olan Risk Faktörleri

\begin{tabular}{lllll}
\hline Değişkenler & $\boldsymbol{p}$ & $\mathbf{0 . 0 .}$ & Minimum & GA \\
\hline Ailede kilolu birey varlı̆̆ı (Evet) & $<.001$ & 14.566 & 4.094 & 51.825 \\
\hline Bilgisayarda vakit geçirme süresi (60 dk. ve üstü) & .128 & 0.331 & 0.080 & 1.373 \\
\hline Okul harici ders çalışma/ödev yapma süresi (2-4 saat arası) & .681 & 1.449 & 0.248 & 8.472 \\
\hline Dershaneye/kursa gitme (Evet) & $<.011$ & 1.121 & 0.033 & 0.453 \\
\hline Bilgisayar/TV izlerken yiyecek yeme (Evet) & $<.011$ & 1.221 & 0.068 & 0.722 \\
\hline
\end{tabular}

$O O=$ Odds Oran1. GA = Güven Aralığ $p<.01 \quad p<.001$

Tek değişkenli lojistik regresyon analizi sonucunda anlamlı olan değişkenler arasındaki en önemli risk faktörünü belirlemek için daha ileri analiz olan çoklu lojistik regresyon analizi yapılmıştır. Buna göre, ailede kilolu birey varlığ 1 (OO =14.56, \%95 GA = 4.09-51.82), dershaneye/kursa gitme $(\mathrm{OO}=1.12, \% 95 \mathrm{GA}=.03-.45)$ ve bilgisayar/TV izlerken yiyecek yeme $(\mathrm{OO}=1.22, \% 95$ GA = .06-.72) fazla kiloluluk ve obezite riskini artırmaktadır. Lise öğrencilerinde fazla kiloluluk ve obezite için en önemli risk faktörleri ailede kilolu birey varlığı, dershaneye/kursa gitme ve bilgisayar/TV izlerken yiyecek yemedir (Tablo 4).

\section{Tartışma}

Çocukluk çağı obezite prevelansının dünyada giderek artması kronik hastalıklar yönünden tehdit edicidir. Obezitenin gelişiminde hem çevresel hem de biyolojik faktörler etkilidir (2,26). Dünyadaki çalışma örnekleri incelendiğinde Amerika'da adölesan obezite ve fazla kilolu prevelansı \%41 (27), Çin'de adölesan obezite ve fazla kilolu prevelansı \%19.9 (24), Brezilya'da 21.3 (19), Hindistan'da \%20.2 (28), Yunanistan'da \%22.2'dir (20). Bu araştırmada, lise öğrencilerinde obezite ve fazla kilolu prevelans1 \%10.9 bulunmuştur. Literatür incelendiğinde Türkiye'nin farklı illerinde yapılan çalışmalarda obezite ve fazla kilolu prevelansı \%9-\%29.8 aralığındadır (5,6,29-31). Türkiye'de yapılan çalışmalardaki obezite prevelansının farklı olmasının sebebi çalışmaların farklı bölge ve okul türlerinde yapılmış olmasından kaynaklandığı düşünülmektedir. Çalışmamızın obezite ve fazla kilolu prevelansı Türkiye'deki diğer çalışmalara göre alt sınırlarda olduğunu belirtmek gerekir.

$\mathrm{Bu}$ araştırmada vaka grubundaki öğrencilerin çoğunu erkek öğrenciler oluşturmaktadır. Önceden yapılmış araştırmalar incelendiğinde adölesan dönemde erkek cinsiyette obezite prevelansı daha fazla görülmektedir $(21,29,32)$. Çalışmalar incelendiğinde Honório ve ark. (2014)'nın vaka kontrol çalışmasında vakaların \%60'ını erkek öğrenciler oluşturmaktadır (19). Bhuiyan ve ark. (2013)'nın vaka kontrol çalışmasında ise vakaların \%56'sını erkekler oluşturmuştur (21). COVID-19 sürecinde de erkek çocuklarda görülen obezite prevelansı daha yüksek bulunmuştur $(9,33)$. Tüm bu çalışmalarda erkeklerin obezite olma sıklığı kızlara göre anlamlı olarak fazla bulunmuştur. Cinsiyete ilişkin bu fark genç kızların toplumun etkisiyle cinsiyet normları ve feminen ideallerden etkilenerek beden merkezli yaklaşım göstermesiyle ilişkilendirilebilir. Adölesan dönemde özellikle kız cinsiyette görülen beden imajı algısı kızlarda fiziksel aktivite ve diyet yapmasına sebep olabilmektedir (34).

Fazla kilolu ve obez grubundaki öğrencilerin ailelerinde kilolu birey varlığı kontrol grubuna göre anlamlı olarak daha fazladır. Fazla kilolu ve obez öğrencilerin ebeveynlerinin beden kitle indeksleri de daha yüksektir. Ayrıca çalışmamızın çoklu lojistik regresyon analizi sonucunda, ailede fazla kilolu bireyin varlığı fazla kiloluluk ve obezite riskini artırmaktadır. Bir araştırma sonucuna göre, ailesinde obez olan bireyin ailesinde obez olmayan bireye göre obez olma riski iki ile sekiz kat daha fazladır (34). Genetik kalıtımın obezite dahil olmak üzere hastalıkların gelişimi ile bağlantılı olduğu bilinmektedir (35). Ailenin genetik yapısının yanı sıra kültürel beslenme ve fiziksel aktivitede (sosyo-ekonomik düzey) obezitenin gelişiminde etkisi olan diğer değişkenlerdir (26). Öztürk ve Aktürk (2011)'ün çalışmasında vaka grubundaki öğrencilerde kontrol grubuna göre şişman kardeş bulunma oranı daha fazladır (7). Aktaş ve ark. (2015)'nın çalışmasında ailesinde obezite öyküsü olan öğrencilerin obez olma riski ailesinde obez olmayan öğrencilere göre 1.27 kat fazla olup, istatistiksel olarak anlamlı bulunmuştur (5). Genetik faktörlerin yanı sıra kültürel inançlar, değerler ve beslenme tercihleri (trans yağ, şeker, tuz, daha büyük porsiyonlar, işlenmiş gıdalar ve atıştırmalık yiyeceklerin tüketimi) de aile içinde obeziteye neden olmaktadır (36). Dolayısı ile bu sonuçlara ulaşılmasının sebepleri aile genetik yapısı ve çevresel faktörler olabileceği düşünülmektedir.

Fazla kilolu ve obez öğrencilerin son bir yıl içerisindeki haftalık fiziksel aktivite sıklığı ve günlük fiziksel aktivite süresi kontrol grubuna göre daha düşüktür. Öztürk ve Aktürk (2011)'ün çalışmasında gün içinde az hareketli olma obezite riskini on kat artırmaktadır (7). Daha sık fiziksel aktivite yapan lise öğrencilerinde aşırı kilo ve obezite prevelansı daha düşüktür. Bu durumun sebebi, fiziksel aktiviteler yapmanın vücut yağını yakarak fazla kilo ve obezite riskini azaltması ile ilişkilidir $(37,38)$. Fiziksel aktivitenin aşırı kilo ve obezite oluşumu önlemek adına koruyucu olduğu diğer çalışmalarla da desteklenmektedir $(19,21,39,40)$.

Fazla kilolu ve obez öğrencilerin son bir yll içerisinde günlük televizyon izleme ve bilgisayarda vakit geçirme süresi kontrol grubuna göre anlamlı olarak daha fazla iken günlük akıllı telefon kullanma süresinde anlamlı bir fark bulunamamıştır. Bunun sebebinin teknolojinin gelişmesiyle bir ihtiyaç haline dönüşen akıllı telefonun adölesan dönemde tüm öğrencilerde yaygın olarak kullanıldığı şeklinde yorumlanabilir. Akıllı telefon kullanımı, yürüme gibi fiziksel aktivite miktarını azaltarak fiziksel sağlığı olumsuz yönde etkilemekte bu da yağ kütlesinin artmasına neden olabilmektedir (41). Dolayısıyla akıllı telefon adölesan dönemde öğrencileri sedanter yaşama iterek obezite riski yaratsa da vaka ve kontrol grubunda benzer sürede kullanıldığı için fark ortaya çıkmamıştır. Bu çalışmada adölesanların son bir yıl içerisinde günlük bilgisayarda vakit geçirme süresinin $60 \mathrm{dk}$. Dokuz Eylül Üniversitesi Hemşirelik Fakültesi Elektronik Dergisi https://dergipark.org.tr/tr/pub/deuhfed 
üzerinde olması fazla kilolu ve obez olma riskini 5.42 kat artırmaktadır. Bilgisayar oyunları ve televizyon programları şeklindeki teknolojik gelişmeler dünyanın her yerinde öğrencilerin daha az fiziksel aktivite yapmasına ya da daha hareketsiz aktivite içeren bir yaşam tarzını benimsenmesine sebep olmaktadır. Pakistan'da çocuklarda yapılan vaka kontrol tasarımlı bir çalışmada günde 4 saatten fazla TV izlemenin obezite için 1.52 kat risk yarattığı tespit edilmiştir (40). Brezilyalı adölesanlarda yapılan bir çalışmada günde 4 saatten fazla bilgisayar kullanma ve TV izlemenin obezite riskini 1.76 kat arttırdığı belirlenmiş̧ir (15). Amerika'da yapılan bir başka çalışmada, günde 2 saatten fazla televizyon veya video izlemenin çocuklarda obezite riskini artırdığı belirlenmiştir (11). COVID-19 sürecinde sosyal alan kısıtlamaları ve okulların kapalı tutulmasıyla birlikte öğrencilerin ev içinde bilgisayar ve telefonda vakit geçirme (ödev, oyun, film vs.) süreleri artmıştır. Ayrıca oyun alanları, park ve bahçelerin kısıtlanması ile ev içinde sedanter davranışları artmış buna bağlı olarak çocukluk obezite oranlarında artış yaşanmıştır $(42,43)$. Genel olarak, sedanter davranışlara sebep olan TV izleme ve bilgisayar kullanma çocukların dışarıda oyun oynama ve fiziksel aktivite yapmasını engellediğinden dolayı obezite için bir risk oluşturmaktadır (11). Yapılan diğer çalışmalarla da bu bilgi desteklenmektedir $(14,22,39)$.

Ders çalışma süresinin fazla olması ve dershaneye ve kursa gitme ile fazla kiloluluk ve obezite arasında anlamlı bir ilişki vardır. Fazla kilolu ve obez öğrencilerin daha fazla ders çalıştı̆ı belirlenmiştir. Çalışmamızda, son bir yıl içerisinde dersaneye/kursa gitme fazla kiloluluk ve obezite riskini artırmaktadır. Adölesan dönemde ev ödevi sayısındaki fazlalık, okul saatleri dışında ders amaçlı kurslara katılma gibi okula ilişkin sedanter davranışlar da obeziteye neden olan risk faktörleri arasındadır $(17,44)$. Öğrencilerin okul ve dershane nedeniyle gün boyunca dışarda vakit geçirmeleri daha fazla hazır besinleri tüketmeleri nedeniyle fazla kalori alımının obezite riskini artırabileceği düşünülmektedir.

Fazla kilolu ve obez öğrencilerin son bir y1l içerisinde okul içinde spor aktivitelerine (voleybol, futbol, hetbol vb.) katılımı daha düşüktür. Okulla ilişkili faktörler arasında okul içi spor aktivitelerine teşvik edici okul çevresi önemlidir. Öğrenciler günlerinin çoğunu okulda geçirmekle birlikte ve teneffüslerde ve beden eğitimi derslerinde oyun oynamak fiziksel aktivitelerinin büyük bir bölümünü oluşturmaktadır (16). Okulda spor aktivitelerine katılım öğrencileri fiziksel aktivite yapmaya teşvik etmekle birlikte olumlu ve aktif bir ortam oluşturabilir.

Fazla kilolu ve obez öğrenciler son bir yıl içerisinde TV izlerken ve bilgisayar kullanırken daha fazla yiyecek yediklerini belirtmişlerdir. $\mathrm{Bu}$ araştırmada, TV/bilgisayar izlerken yiyecek yeme obezite için 1.22 kat daha fazla risk oluşturduğu belirlenmiştir. Televizyon ve bilgisayar karşısında oturarak atıştırma şeklindeki beslenme düzeninin obezite için bir risk olduğu yapılan araştırmalar ile de desteklenmektedir $(5,32)$. Televizyon ve bilgisayar karşısında oturarak veya ayaküstü atışırma şeklindeki beslenme düzeninin kiloluluk ve obeziteye neden olduğu belirtilmektedir. Öğrenciler, TV/bilgisayar izlerken hem sedanter yaşam davranışlarında bulunmakta hem de sağlıksız atıştırmalıklar tüketmekte bununla birlikte vücut yağ dokusu artmakta kas dokusu azalmaktadır (45).

\section{Kisitlılıklar}

$\mathrm{Bu}$ çalışmanın birkaç sınırlılıkları bulunmaktadır. Birincisi, fazla kiloluluk ve obezite ile ilişkili faktörlerin incelenmesinde verilerin öğrencilerin öz bildirimine dayalı toplanmasıdır. İkincisi, öğrencilerin aç karnına kilo ölçümlerinin yapılamamasıdır. Üçüncüsü ebeveynlerin BKİ ölçümlerinin öğrencilerin bildirimine dayalı olmasıdır. Dördüncüsü, fazla kiloluluk ve obezite için risk faktörü olarak incelenen "sedanter yaşam ve beslenme davranışı" değişkenlerinin literatüre dayalı soru formuyla ölçülmüş olup standardize ölçüm araçları kullanılmamıştır.

\section{Sonuçların Uygulamada Kullanımı}

Sonuç olarak, bu çalışma Türkiye'de bir halk sağlığı sorunu olan ergenlerde fazla kilo ve obezitenin önemini vurgulamaktadır. Öğrencilerde fazla kiloluluk ve obeziteye neden olan risk faktörleri, ailede kilolu bireyin varlı̆̆ı, son bir yıl içinde günlük 60 dk.'dan fazla bilgisayarda vakit geçirme, dershaneye/kursa gitme ve bilgisayar/TV izlerken yiyecek yeme olarak bulunmuştur. Obeziteyi önlemek için; okul sağlığı hemşiresi tarafından sağlıklı beslenme ve fiziksel aktiviteye yönelik eğitimler verilmesi, beden eğitimi derslerinin özendirilmesi, öğrencilerin akademik başarısı kadar beden ve ruh sağlığının da önemi konusunda farkındalık yaratılması, okul bahçesinin fiziksel aktiviteyi özendirici şekilde geliştirilmesi, kantinlerde yağ ve karbonhidrat ağırlıklı atıştırmalıkların kaldırılması, okul yemekhanelerinde sağlıklı ve lezzetli besin türlerinin artırılması önerilebilir. Ayrıca, ev içinde bilgisayar/TV izlerken sağlıklı atıştırmalıkların tercih edilmesi (meyve, çiğ kuruyemiş vb.), bilgisayar kullanımın azaltılması, bilgisayar karşısında yiyecek tüketilmemesi ve gün içinde en az bir saat fiziksel olarak aktif olunması önerilmektedir.

\section{Bilgilendirme}

Yazarların katkı oranı beyanı şöyledir: Fikir/Tasarımı: AK, EK; Veri toplama: EK; Veri analizi ve yorumlama: EK, AK; Yazıyı Yazma: EK; İçeriğin eleştirel incelenmesi: AK; Son onay ve sorumluluk: AK, EK; araştırmanın bütçesi: EK, AK. Araştırma ile ilgili herhangi bir projeden ya da firmadan destek alınmamışır. Araştırma bütçesi, araştırmacılar tarafından karşılanmışıtır. Yazarlar arasında herhangi bir çıkar çatışması yoktur. Ayrıca sorumlu olduğumuz araştırmada herhangi bir firma ile çıkar ilişkisi yoktur. Araştırmanın yapılabilmesi için Girişimsel Olmayan Klinik Araştırmalar Etik Kurulu’ndan (Tarih: 22/01/2019 Sayı: 60116787-020/16167) izin alınmıştır. 


\section{Kaynaklar}

1. Yurt S. Okul sağlığında özel sorunlar: Obezite. İçinde Gözüm S, Okul Dönemindeki Çocukların Sağlığının Geliştirmesi. 1. Bask1. İstanbul: Vize; 2016: 342-46.

2. World Health Organization. Overweight and obesity. Children and Adolescent aged 5-19. 2018; URL:https://www.who.int/gho/ncd/risk_factors/overweight_adolescents_text/en/ 01.10.2020

3. World Health Organization. Obesity. 2018. URL:https://www.who.int/topics/obesity/en/ 11.11.2020

4. Centers for Disease Control and Prevention. About BMI for Children \& Teens. 2018. URL:https://www.cdc.gov/healthyweight/assessing/bmi/childrens bmi/about_childrens bmi.html 01.10.2020

5. Aktaş D, Öztürk FN, Kapan Y. Adölesanlarda obezite sıklığı ve etkileyen risk faktörleri, beslenme alışkanlıklarının belirlenmesi. TAF Preventive Medicine Bulletin 2015;14(5): 406-12.

6. Yılmaz M, Mayda AS. Determination of the obesity prevalence and risk factors in school children in Düzce. Düzce T1p Fakültesi Dergisi 2017;19(2): 42-47.

7. Öztürk A, Aktürk S. İlköğretim öğrencilerinde obezite prevalansı ve ilişkili risk faktörleri. TAF Preventive Medicine Bulletin 2011;10(1): 53-60.

8. Wen J, Zhu L, Ji C. Changes in weight and height among Chinese preschool children during COVID-19 school closures. International Journal of Obesity 2021; 1-5.

9. Kim ES, Kwon Y, Choe YH, \& Kim MJ. COVID-19-related school closing aggravate obesity and glucose intolerance in pediatric patients with obesity. Scientific Reports 2021; 11(1), 1-7.

10. Rubenstein C. Child and adolescent health. In: Stanhope M, Lancaster J, editors. Public Health Nursing: PopulationCentered Health Care in the Community. Missouri: Elsevier; 2012. p. 654-57.

11. Mendoza JA, Zimmerman FJ, Christakis DA. Television viewing, computer use, obesity, and adiposity in US preschool children. International Journal of Behavioral Nutrition and Physical Activity 2007;4(1): 1-10.

12. GodakandaI, Abeysena C, Lokubalasooriya A. Sedentary behavior during leisure time, physical activity and dietary habits as risk factors of overweight among school children aged 14-15 years: case control study. BMC Research Notes 2018;11(1): $1-10$.

13. Allender JA, Rector C, Warder KD. School-age children and adolescent. In: Community \& Public Health Nursing Promoting the Public's Health. 8rd ed. China: Wolters Kluwer Health; 2014. p. 717-19.

14. Rathnayake KM, Roopasingam T, Wickramasighe VP. Nutritional and behavioral determinants of adolescent obesity: a case-control study in Sri Lanka. BMC Public Health 2014;14(1):1-6.

15. Kim SE, Kim JW, Jee YS. Relationship between smartphone addiction and physical activity in Chinese international students in Korea. Journal of Behavioral Addictions 2015;4(3):200-205.

16. Li M, Dibley MJ, Sibbritt D, Yan H. Factors associated with adolescents' overweight and obesity at community, school and household levels in Xi'an City, China: results of hierarchical analysis. European Journal of Clinical Nutrition 2008;62(5): 635-45.

17. Martin A, Booth JN, Laird Y, Sproule J, Reilly JJ, \& Saunders DH. Physical activity, diet and other behavioural interventions for improving cognition and school achievement in children and adolescents with obesity or overweight. Cochrane Database of Systematic Reviews 2018;(1): CD009728.

18. Erol S. Okul sağlığı taramaları. İçinde Gözüm S, Okul Dönemindeki Çocukların Sağlığının Geliştirmesi. 1. Baskı. İstanbul: Vize; 2016: 114-16.

19. Honório RF, Hadler MCCM. Factors associated with obesity in Brazilian children enrolled in the School Health Program: a case-control study. Nutricion Hospitalaria. 2014;30(3): 526-34.

20. Patsopoulou A, Tsimtsiou Z, Katsioulis A, Rachiotis G, Malissiova E, Hadjichristodoulou C. Prevalence and risk factors of overweight and obesity among adolescents and their parents in central Greece (FETA Project). International Journal of Environmental Research and Public Health. 2016;13(1): 1-10.

21. Bhuiyan MU, Zaman S, Ahmed T. Risk factors associated with overweight and obesity among urban school children and adolescents in Bangladesh: a case-control study. BMC Pediatrics. 2013;13(1): 1-6.

22. Neutzling MB, Taddei JAA, Gigante DP. Risk factors of obesity among Brazilian adolescents: a case-control study. Public Health Nutrition. 2003;6(8): 743-49.

23. T.C. Millî Eğitim Bakanlığı. Eğitimi Araştırma ve Geliştirme Dairesi Başkanlığı. Öğrencilerin Okul Kantinlerindeki Tüketim Tercihleri ve Kantinlerin Değerlendirilmesi. Ankara; 2008. p. 17-19.

24. Kudret M, Budak N. Kuzey Kıbrıs Türk Cumhuriyeti Doğu Akdeniz Üniversitesi Öğrencilerinin Sabah Kahvaltısı Yapma Alışkanlıklarının Saptanması. International Peer-Reviewed Journal of Nutrition Research. 2017;9: 51-64.

25. World Health Organization. WHO child growth standards: training course on child growth assessment. Switzerland: WHO Press; 2018. p. 15-18.

26. Campbell ET, Franks AT, Joseph PV. Adolescent obesity in the past decade: A systematic review of genetics and determinants of food choice. Journal of the American Association of Nurse Practitioners. 2019;31(6): 344-51.

27. Centers for Disease Control and Prevention. National Center for Health Statistics. Children and Adolescents: Percentage of Children and Adolescents Who are Overweight or Obese. 2018. URL: https://nccd.cdc.gov/CKD/detail.aspx?QNum=Q248 11.11.2020

28. Nirmala A, Venkataraman P, Kanniammal C, Rani A, Arulappan J. Prevalence of Obesity and Associated Risk Factors among Adolescents in Kancheepuram, south India. International Journal of Nursing Education. 2018;10(1): 55-60.

29. Meşe Yavuz C, Koca Özer B. Adölesan dönem okul çocuklarında beslenme alışkanlıkları ve beslenme durumunun değerlendirilmesi. Journal of Tourism and Gastronomy Studies. 2019;7(1): 225-43. 
30. Yılmaz SK, Özel HG. Okul çağı çocuklarda şekerli içecek tüketimi ile obezite riski arasındaki ilişki. Beslenme ve Diyet Dergisi. 2016;44(1): 3-9.

31. Agadayı E, Çelik N, Çetinkaya S, Karaca SN. Sivas ili kırsal bir ilçede okul çağı çocuklar ve adölesanlarda obezite sıklığının ve etkileyen faktörlerin belirlenmesi. Ankara Medical Journal. Ankara Medical Journal. 2019;19(2): 325-36.

32. Gürel AN, Hisar F. Adölesanlarda şekerli içecek tüketiminin obezite ile ilişsisi. Hacettepe University Faculty of Health Sciences Nursing Journal. 2018;5(3): 177-91.

33. An R. Projecting the impact of the coronavirus disease-2019 pandemic on childhood obesity in the United States: A microsimulation model. Journal of sport and health science 2020; 9(4), 302-312.

34. Spencer RA, Rehman L, Kirk SF. Understanding gender norms, nutrition, and physical activity in adolescent girls: a scoping review. International Journal of Behavioral Nutrition and Physical Activity 2015;12(1): 1-10.

35. Qi L, Cho YA. Gene-environment interaction and obesity. Nutrition Reviews 2008;66(12):684-94.

36. Van Dijk SJ, Molloy PL, Varinli H, Morrison JL, Muhlhausler BS. Epigenetics and human obesity. International Journal of Obesity. 2015;39(1): 85-97.

37. Travis S, Bisogni C, Ranzenhofer L. A conceptual model of how US families with athletic adolescent daughters manage food and eating. Appetite. 2010;54(1):108-17.

38. Guerra S, Teixeira-Pinto A, Ribeiro JC, Ascensão A, Magalhães J, Andersen LB ve ark. Relationship between physical activity and obesity in children and adolescents. Journal of sports medicine and physical fitness. 2006;46(1): 79-83.

39. Muthuri SK, Wachira LJM, Onywera VO, Tremblay MS. Correlates of objectively measured overweight/obesity and physical activity in Kenyan school children: results from ISCOLE-Kenya. BMC Public Health. 2014;14(1): 436.

40. Anteneh ZA, Gedefaw M, Tekletsadek KN, Tsegaye M, Alemu D. Risk factors of overweight and obesity among high school students in Bahir Dar City, north West Ethiopia: school based cross-sectional study. Advances in Preventive Medicine. 2015;3:1-9.

41. Rizwan W, Bhatti T. Risk factors for development of obesity in children. Pakistan Journal of Medical \& Health Sciences. 2017;11(1): 438-40.

42. Hadianfard AM, Mozaffari-Khosravi H, Karandish M, \& Azhdari M. Physical Activity and Sedentary Behaviors (Screen Time and Homework) Among Overweight or Obese Adolescents Before The COVID-19 Pandemic: A Cross-Sectional Observational Study in Yazd, Iran. BMC Pediatr. 2021;21(1):421.

43. Rundle AG, Park Y, Herbstman JB, Kinsey EW, \& Wang YC. COVID-19 related school closings and risk of weight gain among children. Obesity (Silver Spring). 2020;28(6):1008.

44. Yılmaz BÖ, Çiçek B, Kaner G. Kayseri İlindeki liselerde öğrenim gören adölesanlarda obezite düzeyinin ve ilişkili risk faktörlerinin belirlenmesi. Türk Hijyen ve Deneysel Biyoloji Dergisi 2018;75(1): 77-78.

45. Ren H, Zhou Z, Liu W, Wang X, Yin Z. Excessive homework, inadequate sleep, physical inactivity and screen viewing time are major contributors to high pediatric obesity. Acta Paediatrica. 2017;106(1): 120-27. 